\title{
Relationship between Inferiority complex and Frustration in Adolescents
}

\author{
${ }^{1}$ Rajeshwari. N. Kenchappanavar \\ Associate Professor Dept of Psychology Karnatak Arts College, Dharwad, India
}

\begin{abstract}
The present study is an attempt to investigate the relationship between Inferiority complex and Frustration in adolescents. It was conjectured that Inferiority complex in adolescents is positively correlated with Frustration resulting in reactions of Aggression, Resignation, Fixation and Regression. The sample comprised of 100 pre-University college students in the age range of 16-18. The results revealed that Inferiority complex correlated significantly with Frustration. The correlation was specifically high on Aggression ( $r=0.516)$, Resignation ( $r=0.413)$ and Frustration on the whole. $(r-0.511)$. Further regression analysis was carried out to see whether Frustration would predict Inferiority complex. It was revealed that Frustration significantly predicts Inferiority complex.
\end{abstract}

Key words: Inferiority complex, Frustration, Aggression, Resignation, Fixation, \& Regression

\section{Introduction}

The problem of Inferiority complex among adolescents is becoming increasingly alarming. Teenage years are the prime years of bearing the burden of inferiority feelings. Inferiority complex is a kind of psychological obstacle that occurs usually in puberty and its reasons are complicated and its effects negative and harmful [1].

According to Adler [2], Inferiority complex arises when a person finds himself in a situation where his abilities and attitudes are denigrated or rejected by other people [3]. Inferiority complex is a magnification of natural feelings of inferiority and results when strivings to overcome inferiority are greatly hindered. Anything in the individual that is below the average ,that provokes unfavourable comment or gives him a feeling of impotency or ineptitude leads to inferiority complex[4].Adolescents who consistently fail or repeat classes are found to develop inferiority complex and a non progressive attitude towards school and peers [5]. High degree of parental demands and expectations may lead to inferiority feelings [6].Inferiority complex is an exaggeration of normal inferiority feelings and individuals with inferiority complex display a tendency towards overcompensation and over reaction [7].

Inferiority complex or lack of self-esteem [8] leads to negative or risk seeking behaviors in young people. Theoretical and correlational analyses have yielded tenuous associations between low self-esteem and socially problematic outcomes or risk taking behaviors like substance abuse, aggression\& poor school achievement [9]; [10]; 11]. Frustration is a response to low self -esteem [12]; [13]. Inferiority complex generates hostile frustration [14].

Frustration is a state of emotional stress characterized by confusion, annoyance and anger [15]. Interruption to goal seeking behavior causes frustration. The person's awareness of his inability to satisfy his drives and his failure to reach the goals he has set for himself makes him helpless and he suffers from injured pride [16] leading to frustration. Frustration is expressed in various modes-Aggression ,Resignation, Fixation and Regression [17].

According to Freud (18], Aggression is an expression of Frustration. Frustration always leads to some form of aggression [19]; [14]; [20]; [21].Aggression increases if a person feels that he/she is being blocked from achieving a goal [22].

Sometimes frustration leads to resignated behavior. There is extreme elimination of needs, no plans, no future orientations, withdrawal from social contacts, isolation, lack of interest in the surroundings .Persons with severe frustration may try to escape or withdraw from certain situations [23 ].

Maier [24]; [25] contends that frustration is expressed in Fixated behaviors- behaviors that are stereotyped and extremely persistent. Fixated behaviors are non adaptive [26]. Freud [18] has also suggested Frustration-Regression hypothesis. According to him frustration could cause an individual to revert to modes of action that had characterized his behavior to earlier developmental stage. People resort to regressive behavior due to frustration [27]

Inferiority feelings when intensified by external causes can lead to frustration getting manifested through various symptoms of either withdrawal or aggressive acts [28]. Hence in the present study an attempt is made to investigate the relationship between Inferiority complex and Frustration.

Hypothesis: Inferiority complex is positively correlated with Frustration. 


\section{Method}

Sample: A total of 100 adolescents (50 boys and 50 girls) in the age range of 16-18 were selected by using systematic random sampling procedure. The adolescent respondents were selected from three pre-degree colleges of Dharwad town, Karnataka. The colleges had same educational affiliation and catered to loweconomic to middle economic students.

Tools:

1. Inferiority-Insecurity Questionnaire by Dr.G.C.Pati [29]. The scale has a sufficiently high validity ( Validity Co-efficient $\mathrm{R}=.717$ ) and a high test-retest reliability. (Reliability co-efficient $\mathrm{r}=.92$ )

2. Reactions to Frustration Scale (RFS) by Dixit and Srivastav [30]. The scale covers four reactions namelyAggression, Resignation, Fixation and Regression as scientifically described by [24].It consists of 40 items out of which each reaction has 10 items equally divided into positive and negative items. The scale has satisfactory reliability and validity.

III. Results and Discussion

Table-1: Descriptive statistics of variables

\begin{tabular}{|l|l|l|l|}
\hline & Mean & Std. Deviation & $\mathrm{N}$ \\
\hline $\begin{array}{l}\text { Inferiority } \\
\text { complex }\end{array}$ & 69.5560 & 16.78068 & 100 \\
Aggression & 25.8200 & 4.85628 & 100 \\
Resignation & 23.4100 & 5.57428 & 100 \\
Fixation & 26.7900 & 5.99713 & 100 \\
Regression & 31.6400 & 5.37769 & 100 \\
Total & 107.6600 & 12.77562 & 100 \\
Frustration & & & \\
\hline
\end{tabular}

Table -2 showing correlation between Inferiority complex and Frustration and Reactions to Frustration.

Reactions to Frustration

\begin{tabular}{|c|c|c|c|c|c|c|}
\hline Varible & $\begin{array}{l}\text { Inferiority } \\
\text { complex }\end{array}$ & Agression & Resignatin & Fixation & Regresson & Total \\
\hline $\begin{array}{l}\text { Inferiority } \\
\text { Complex }\end{array}$ & - & $.516^{* *}$ & $.438^{* *}$ & .103 & .179 & $.511^{* * *}$ \\
\hline
\end{tabular}

$* * \mathrm{p}<0.01$ level

Table 3 Step-wise Multiple Regression Analysis of Frustration on Inferiority complex

\begin{tabular}{|l|l|l|l|l|l|l|}
\hline Sl.No. & $\begin{array}{l}\text { Contributing } \\
\text { Variables }\end{array}$ & $\begin{array}{l}\text { Beta } \\
\text { Coefficients }\end{array}$ & $\begin{array}{l}\text { Standard } \\
\text { Error }\end{array}$ & $\begin{array}{l}\text { Contrib- } \\
\text { uted R }\end{array}$ & F-value & t- value \\
\hline 1 & Aggression & .149 & .025 & .259 & $35.613^{*}$ & 5.968 \\
\hline 2 & Resignation & .145 & .030 & .183 & $23.203^{*}$ & 4.817 \\
\hline 3 & Total & .389 & .066 & .253 & $34.586^{*}$ & 5.881 \\
\hline
\end{tabular}

$* \mathrm{P}<.001$

\section{Results and Discussion:}

It can be inferred from the descriptive statistics from Table-1 that Adolescents have intense feelings of Inferiority (mean=69.5; SD-16.7)and high Frustration (mean=107.6; SD=12.7)

Table 2 shows the relationship between Inferiority complex and the four types of reactions to Frustration and Frustration on the whole. The results reveal that Aggression ( $r=0.51 \quad \mathrm{p}<0.01)$, Resignation $(\mathrm{r}=0.41 \mathrm{p}<0.01)$ and Frustration on the whole $(\mathrm{r}=0.51 \mathrm{p}<0.01)$ were found to have significant positive association with Inferiority complex. The present findings are in agreement with the findings of Wright,1995 [31] who has reported that intense feelings of Inferiority or low self esteem is associated with impulsivity and aggressiveness. Frustration results in aggression; aggression stems from frustration [32]. Children with inferiority complex and insecure attachments come to believe that others will treat them badly. These beliefs and feelings help to develop dispositions to initiate conflicts, oppose actions of others and behave aggressively 
[33]. Lack of recognition and respect for people's identity can lead to aggressive acts [34]. Increase in aggressive behavior was noticed in subjects with low self-esteem [35].

Inferiority complex may lead to pessimistic resignation and an assumed inability to overcome difficulties [36]. An Inferiority complex is an advanced state of discouragement often embedding itself into one's life style and sometimes resulting in a retreat from difficulties [37]. People with intense Inferiority feelings tend to adopt non-assertive [38] and submissive defensive behavior [39]; [40] ; [41].

Inferiority feelings when intensified by external causes lead to Frustration and may be manifested through various symptoms of either withdrawal or aggressive acts [28].

A perusal of Correlation results suggested calculation of step-wise multiple regression to identify percent contribution of predictors in Criterion variable. Regression results ( Table 3) showed that Frustration as a whole was a significant predictor of Inferiority complex ( $\mathrm{Beta}=.389 \mathrm{R}^{2}=.25, \mathrm{~F}=34.58, \mathrm{P}<.01$ ). Frustration as a whole has contributed $25 \%$ variance. Similarly Aggression is also explained by Inferiority complex (Beta $=.149, \mathrm{R}^{2}=.25, \mathrm{~F}=23.2 \mathrm{p}<0.01$ ). Aggression too contributed $25 \%$ variance. Resignation (Beta $=.145, \mathrm{R}^{2}$ $=.18, \mathrm{~F}=23.2 \mathrm{p}<0.01)$ has contributed $18 \%$ variance to Inferiority complex.

Results of the study evinced the adverse consequences of Frustration on the development of Inferiority complex in adolescents. Studies reveal that Inferiority complex may produce a personality characterized by neurotic tendencies [2] and intense frustration leading to anti-social behavior [ 42]. Intense reactions to Frustration may interfere with learning process which in turn can lead to emotional maladjustment [43].Rejected and neglected students are aggressive and disruptive [44]. Aggressive behaviors during adolescence serve as the strongest predictors of adjustment problems during adulthood [45].

Inferiority feelings or low self-esteem interferes with motivation and pro-activity that leads to an avoidant and passive interaction style [46]. Inferiority complex, low self esteem and academic failures are highly correlated [47]. Socially rejected children appear at risk for academic failure [48]. Students with inferiority complex tend to possess undesirable attributes such as passive dependency, poor social skills, defeatist attitudes and general incompetency [49].Hence it is important that to the extent possible parents, teachers ,supervisors and others strive to maximize self-enhancing experiences and minimize self-denigrating experiences [50,] to help adolescents overcome inferiority complex and the resultant frustration.

\section{References}

[1] LIN, Jing(2000): Produce, Harm and overcome of sense of Inferiority in the Puberty. Journal of Fuzhou Teachers College, 200005

[2] Adler, Alfred (1907): Study of organ inferiority and its Psychical compensation:A contribution to clinical medicine. Nervous and Mental Disease Monograph series,No.24. New-York: Nervous and mental disease Pub.

[3] Ansbacher, H.L \& Ansbacher,R.R (1964) : The Individual Psychology of Alfred Adler. New-York : Harper Torchbook

[4] Murray,,H.A (1938): Explorations in Personality. New-York: Oxford University Press.

[5] Esfandyari, B ; Baharudin,S ; Nouzari,L (2009): The relationship between Interparental conflicts and externalizing behavior problems among adolescents. European Journal of Social Science,12, 117-122.

[6] Elizabeth B. Hurlock (1981):Developmental Psychology A Life -Span Psycholog.y Fifth Edition Tata-Mc Graw Hill Publishing Company Limited New-Delhi

[7] Heidbreder,E.F (1927): The normal Inferiority complex. The Journal of Abnormal and Social Psychology,22,243-258

[8] Moritz, S; Werner,R \&Collami, G (2006): The inferiority complex in Paranoia readdressed: a study with the Implicit Association Test. Cognition Neuropsychiatry,11,402-415.

[9] Dawes,R.M(1994): House of cards: Psychology and Psychotherapy built on myth. New-York Press:Free Press.

[10] Mecca,A.M ; Smelser,N.J \&Vasoconcelles, J (1989): The Social importance of self-esteem.Berkeley: University of California Press.

[11] Overholser,J.C; Adams,D.M; Lehnert,K.L \&Brinkman,D.C (1995) : Self esteem deficits and suicidal tendencies among adolescents. Journal of American Academy of Child and Adolescent Psychiatry,43,919-929

[12] Kirk ,J \& Reid ,G (2001): An examination of the relationship between Dyslexia and Offending in Young people and the implications for the training systems. DYSLEXIA,7, 77-84

[13] Scott,R (2004): Dyslexia and Counselling . London:Whurs

[14] Dollard ,J; Doob,L.W;Miller,N,E; Mowrer,O,H \&Sears,R,R.(1939): Frustration and Aggression.New Haven,Conn.Yale University Press.

[15] Stagner,R (1961): Psychology of Personality (3rd Edition) . New-York, McGraw Hill

[16] Writ,R.D (1956): Ideational expression of hostile impulses. Journal of consultation Psychology,20,185-189

[17] Eyesenck,H.J (1972): Encyclopedia of Psychology,1 to3, London, Search Press.

[18] Freud,S (1993): New Introductory Lectures on Psycho-analysis. New-York,Norton.

[19] Filer,R.J (1952): Frustration ,Satisfaction and other factors affecting the attractiveness of Goal objects. Journal of Abnormal and Social Psychology,47,203-212.

[20] Miller, N.E.(1941): The frustration-aggression hypothesis. Psychological Review,38, 337-342

[21] McClleland,D.C \& Apicella,F.S (1945): A functional Classification of verbal reactions to experimentally induced failure. Journal of Abnormal and Social Psychology, 40, 376-390

[22] Aronson,E; Akert,M.Robin \& Wilson,D.T (2005): Social Psychology, 5th Edition,Pearson Education,Inc.

[23] Dixit,B.M (1985): The interactive effect of Frustration, adjustment and Sex on Self-concept. Ph.D thesis in Psychology. Agra University.

[24] Maier, N.R.F (1949): Frustration: The Study of Behavior without a Goal. New-York McGraw Hill.

[25] Maier, N.R.F (1956): Frustration Theory: Restatement and Extension. Psychological Review,63,370-388

[26] Mowrer,O.H (1976): Learning Theory and Personality Dynamics. New-York. Ronald Press Company

[27] Lewin,K (1937): Psychoanalytic and Topological Psychology. Bulletin of Menninger Clinic,1,202-211. 
[28] Katz, Barney (1997): The Inferior Complex, some essential causes. Education,69,293

[29] Pati,G,C() The Inferiority\& Insecurity Questionnaires .Rupa Psychological Centre. Varnasi

[30] Dixit ,B.M \& Srivastav,D.N (1997): Reactions to Frustration Scale. National Psychological Corporation,Agra.

[31] Wright,D (1995): The biology of violence. The New-Yorker, 71,68-77

[32] Baron,R.A \&R ichardson,D.R(2004): Human Aggression. New-York: Plenum

[33] Perry,D;Perry, L\& Kennedy,E (1995): Conflict and development of antisocial behavior. In Shantz,C.U and Hartup,W (ed) Conflict in Child and Adolescent development .Cambridge \& Cambridge University Press, pp 301-329

[34] Burton,J (1997): Violence Explained. Manchester. Manchester University Press.

[35] Robert,C,Day,\& Robert,L,Hamblin (1964): Some effects of close and punitive styles of supervision. American Journal of Sociology,69,499

[36] Henry,T.Stein \& Martha, E. Edwards (2003): Classical Adlerian Psychotherapy. The New Encyclopedia of Psychotherapy vol1Laing, R.D(1988): Self and Others. Pelican Books

[37] Arrindell,W.A;Sanderman,R; Hageman,WJJM; Pickersgill,MJ; Kwee MGT; Molen,H.T\& Lingsma,MM (1990): Correlates of assertiveness in normal and clinical samples: A multidimensional Approach. Advances in Behavior Theory and Research,12,15328239. Gilbert,P :Allan,S; Goss,K (1994): An exploration of shame measures II: Psychopathology. Personality and Individual differences, $17,719-722$.

[38] Allan,S \&Gilbert,P (1997): Submissive Behavior and Psychopathology. British Journal of Clinical Psychology,36,467-488.

[39] McGuire,M \& Gilbert,P(1998): Shame,Social roles and Status: The Psychobiological continuum from monkey to human. In ; Interpersonal behavior Psychopathology \& culture,Gilbert,P and Andrews,B (Eds) Oxford University Press,New -York,99-125

[40] Coie,J.D \& Dodge,K.A (1997): Aggression and Antisocial behavior. In W.Damon\& N. Eisenberg (Eds) Handbook of Child Psychology,vol 3. Social Emotional and Personality development

[41] Gladys,Natchez (1961):Oral reading used as an indicator of reaction to frustration. Journal of Educational Research,54,8.

[42] Byrnes,A.D (1984): Forgotten children in classrooms:Development and characteristics. The Elementary School Journal,84, 270281

[43] Kohlberg,L; Ricks,D \& Snarey,J (1984): Childhood Development as a predictor of adaptation in Adulthood. Genetic Psychology Monographs, 110,94-162

[44] Henderson, L \& Zimbardo ,P.G (1996): Encyclopedia of mental Health,3,497-509.San Diego ,Academic Press.

[45] Burns,R.B (1979) :The self-concept in Theory, Measurement, Development and Behavior. London:Longman

[46] Dishion,T.J \&Haas,E \&Li.F (1997) : Friendships and violent behavior during adolescence. Social Development,6,207-223

[47] Coopersmith, S (1967): The Antecedents of self-esteem. San Fransisco :Freeman

[48] Baron ,Robert \&Donn, Byrne ():Social Psychology . Tenth Edition. Pearson Education

[49] Aronson,E; Akert,M.Robin \& Wilson,D.T (2005): Social Psychology, 5th Edition,Pearson Education,Inc.

[50] Baron ,Robert \&Donn, Byrne ():Social Psychology. Tenth Edition. Pearson Education

[51] Baron,R.A \&R ichardson,D.R(2004): Human Aggression. New-York: Plenum.

[52] Burns,R.B (1979) :The self-concept in Theory ,Measurement, Development and Behavior. London:Longman

[53] Byrnes,A.D (1984): Forgotten children in classrooms:Development and characteristics. The Elementary School Journal,84, 270281

[54] Burton,J (1997): Violence Explained. Manchester. Manchester University Press

[55] Coie,J.D \& Dodge,K.A (1997): Aggression and Antisocial behavior. In W.Damon\& N. Eisenberg (Eds) Handbook of Child Psychology,vol 3. Social Emotional and Personality development

[56] Coopersmith, S (1967): The Antecedents of self-esteem. San Fransisco :Freeman

[57] Dawes,R.M(1994): House of cards: Psychology and Psychotherapy built on myth. New-York Press:Free Press.

[58] Dishion,T.J \&Haas,E \&Li.F (1997) : Friendships and violent behavior during adolescence. Social Development,6,207-223

[59] Dollard ,J; Doob,L.W;Miller,N,E; Mowrer,O,H \&Sears,R,R.(1939): Frustration and Aggression.New Haven,Conn.Yale University Press.

[60] Dixit,B.M (1985): The interactive effect of Frustration, adjustment and Sex on Self-concept, Ph.D thesis in Psychology. Agra University.

[61] Dixit ,B.M \& Srivastav,D.N (1997): Reactions to Frustration Scale. National Psychological Corporation,Agra.

[62] Esfandyari, B ; Baharudin,S ; Nouzari,L (2009): The relationship between Interparental conflicts and externalizing behavior problems among adolescents. European Journal of Social Science,12, 117-122.

[63] Eyesenck,H.J (1972): Encyclopedia of Psychology,1to3, London, Search Press.

[64] Filer,R.J (1952): Frustration ,Satisfaction and other factors affecting the attractiveness of Goal objects. Journal of Abnormal and Social Psychology,47,203-212.

[65] Freud,S (1993): New Introductory Lectures on Psycho-analysis. New-York,Norton.

[66] Gilbert,P :Allan,S; Goss,K (1994): An exploration of shame measures II: Psychopathology. Personality and Individal differences, 17,719-722.

[67] Gladys,Natchez (1961):Oral reading used as an indicator of reaction to frustration. Journal of Educational Research,54,8.

[68] Henderson, L \& Zimbardo ,P.G (1996): Encyclopedia of mental Health,3,497-509.San Diego ,Academic Press.

[69] Henry,T.Stein \& Martha, E. Edwards (2003): Classical Adlerian Psychotherapy. The New Encyclopedia of Psychotherapy vol-1

[70] Heidbreder,E.F (1927): The normal Inferiority complex. The Journal of Abnormal and Social Psychology,22,243-258

[71] Katz, B (1997): The Inferior Complex, some essential causes. Education,69,293.

[72] Kirk ,J \& Reid ,G (2001): An examination of the relationship between Dyslexia and Offending in Young people and the implications for the training systems. DYSLEXIA,7, 77-84

[73] Kohlberg,L; Ricks,D \& Snarey,J (1984): Childhood Development as a predictor of adaptation in Adulthood. Genetic Psychology Monographs, 110,94-162

[74] Laing, R.D(1988): Self and Others. Pelican Books

[75] Lewin,K (1937): Psychoanalytic and Topological Psychology. Bulletin of Menninger Clinic,1,202-211.

[76] LIN, Jing(2000): Produce, Harm and overcome of sense of Inferiority in the Puberty. Journal of Fuzhou Teachers College, 200005

[77] Maier, N.R.F (1949): Frustration: The Study of Behavior without a Goal. New-York McGraw Hill.

[78] Maier, N.R.F (1956): Frustration Theory: Restatement and Extension. Psychological Review,63,370-388

[79] McClleland,D.C \& Apicella,F.S (1945): A functional Classification of verbal reactions to experimentally induced failure. Journal of Abnormal and Social Psychology, 40, 376-390

[80] McGuire,M \& Gilbert,P(1998): Shame,Social roles and Status: The Psychobiological continuum from monkey to human. In ; Interpersonal behavior Psychopathology \& culture,Gilbert,P and Andrews,B (Eds) Oxford University Press,New -York,99-125 
[81] Mecca,A.M ; Smelser,N.J \&Vasoconcelles, J (1989): The Social importance of self-esteem.Berkeley: University of California Press.

[82] Miller, N.E.(1941): The frustration-aggression hypothesis. Psychological Review,38, 337-342

[83] Moritz, S; Werner,R \&Collami, G (2006): The inferiority complex in Paranoia readdressed: a study with the Implicit Association Test. Cognition Neuropsychiatry,11,402-415.

[84] Mowrer,O.H (1976): Learning Theory and Personality Dynamics. New-York. Ronald Press Company

[85] Murray,,H.A (1938): Explorations in Personality. New-York: Oxford University Press.

[86] Overholser,J.C; Adams,D.M; Lehnert,K.L \&Brinkman,D.C (1995) : Self esteem deficits and suicidal tendencies among adolescents. Journal of American Academy of Child and Adolescent Psychiatry,43,919-929

[87] Perry,D;Perry, L\& Kennedy,E (1995): Conflict and development of antisocial behavior. In Shantz,C.U and Hartup,W (ed) Conflict in Child and Adolescent development .Cambridge \& Cambridge University Press, pp 301-329

[88] Pati,G,C() The Inferiority\& Insecurity Questionnaires .Rupa Psychological Centre.Varnasi

[89] Robert,C,Day,\& Robert,L,Hamblin (1964): Some effects of close and punitive styles of supervision. American Journal of Sociology, 69,499

[90] Scott,R (2004): Dyslexia and Counselling . London:Whurs

[91] Stagner,R (1961): Psychology of Personality (3rd Edition) . New-York, McGraw Hill

[92] Writ,R.D (1956): Ideational expression of hostile impulses. Journal of consultation Psychology,20,185-189

[93] Wright,D (1995): The biology of violence. The New-Yorker, 71,68-77 